\title{
Nature and Artifice in Hobbes's International Political Thought
}

\author{
Maximilian Jaede \\ School of International Relations \\ University of St Andrews \\ Arts Faculty Building, The Scores \\ St Andrews, KY16 9AX \\ United Kingdom \\ mj327@st-andrews.ac.uk
}

This is a pre-proof version of a paper forthcoming in Hobbes Studies (2015)

\section{Introduction}

Some readers have taken Hobbes's analogy between individuals and states all too literally. For Hannah Arendt, the restless desire for power after power that he posits in Leviathan also applies to commonwealths, which supposedly need to constantly extend their authority simply in order to preserve themselves. ${ }^{1}$ Other commentators associate Hobbes with the so-called 'Westphalian system' of mutually recognised sovereign states. Carl Schmitt, for instance, claims that Hobbesian states are 'moral persons' that confront each other with equal rights and legitimacy. ${ }^{2}$

It is widely agreed that both of these readings are inaccurate. There seem to be important differences between the international and interpersonal states of nature, some of which relate to the fact that Hobbes regards commonwealths as artefacts created for the preservation of individuals. ${ }^{3}$ Thus, there must be limits to the hostility

\footnotetext{
${ }^{1}$ Hannah Arendt, The Origins of Totalitarianism, with an Introduction by Samantha Power (New York: Schocken, 2004), pp. 186-190.

${ }^{2}$ Carl Schmitt, The Nomos of the Earth in the International Law of the Jus Publicum Europaeum, translated and with Introduction by G.L. Ulmen (New York: Telos, 2003), p. 163.

${ }^{3}$ See, for instance, Noel Malcolm, Aspects of Hobbes (Oxford: Clarendon Press, 2002), pp. 432-456; and Gabriella Slomp, "The Politics of Motion and the Motion of Politics," in Raia Prokhovnik and Gabriella Slomp (eds.), International Political Theory After Hobbes: Analysis, Interpretation and Orientation (Basingstoke, UK: Palgrave Macmillan, 2010), pp. 19-41.
} 
between states. ${ }^{4}$ Moreover, Hobbes does not appear to regard states as compound moral persons that have a capacity to have one will, irrespective of the people who institute or represent them. ${ }^{5}$ Rather, commonwealths only exist as long as they are effectively represented by a sovereign, and it is in the latter's self-interest to govern in such a way that does not endanger his position of power. ${ }^{6}$

This article seeks to contribute to a better understanding of Hobbes's international political thought by focussing on the notions of nature and artifice. It aims to clarify in which sense the international state of war can be regarded as natural, and how the artificiality of states bears upon their naturally hostile relations.

The thesis is that, despite the fact that Hobbesian commonwealths find themselves in a state of nature, their artificiality facilitates coexistence, self-restraint in warfare, and reconciliation. In particular, it will be suggested that states could maintain largely peaceful relations based on an artificial equality of power, which has a contrary effect to the natural equality of individuals in the state of nature. Moreover, it will be shown that states could be decomposed and reassembled in order to re-establish peace after foreign invasions. These factors help to explain both why Hobbes considers the international state of nature more bearable than the interpersonal one, and why he does not seem to provide a separate theory of international relations.

\footnotetext{
${ }^{4}$ Stanley Hoffmann suggests that every Hobbesian state has a domestic interest in self-restraint, "since, should it implicate its population in all-out wars of extermination, the duty of obedience of the subjects to the state would disappear." See Hoffmann, "Rousseau on War and Peace", American Political Science Review 57 (1963), pp. 317-333, here 320.

${ }^{5}$ David Boucher, "Resurrecting Pufendorf and Capturing the Westphalian Moment", Review of International Studies 27 (2001), pp. 557-577, here 567.

${ }^{6}$ Tom Sorell, "The Burdensome Freedom of Sovereigns", in Tom Sorell and Luc Foisneau (eds.), Leviathan After 350 Years (Oxford: Clarendon Press, 2004), pp. 183-196, here 184.
} 
The thesis is developed through an analysis of Hobbes's main political works, i.e., Elements of Law, On the Citizen, and Leviathan. ${ }^{7}$ In order to further elucidate claims that Hobbes makes in these texts, I will additionally consider passages from some of his other writings, including Behemoth, the Dialogue of the Common Laws, and his translation of Thucydides' History of the Peloponnesian War. ${ }^{8}$

\section{Individuals and Groups as Enemies by Nature}

Rejecting the idea of natural sociability, Hobbes posits a state of nature in which human beings are defined by their natural faculties, including an equal capacity to kill and get killed. He argues that the war of all against all that would materialise in this condition is avoidable if we follow the laws of nature, which set out how peace can be achieved within a rationally constructed, artificial political order. ${ }^{9}$

From this brief outline of Hobbes's argument two implications can be drawn out.

First, enmity is 'natural' in the sense that it is due to unchanging human

characteristics, such as the desire for self-preservation, yet despite this it is not unavoidable. To the contrary, the natural law prescribes "that every man ought to endeavour peace, as far as he has hope of obtaining it." ${ }^{10}$ While Hobbes suggests that it is not required to grant peace to those individuals who remain in a hostile frame of

\footnotetext{
${ }^{7}$ The following editions will be used: Thomas Hobbes, The Elements of Law: Natural and Politic, ed. with an Introduction by J.C.A. Gaskin (Oxford: Oxford University Press, 1994); Hobbes, On the Citizen, ed. and trans. Richard Tuck and Michael Silverthorne (Cambridge: Cambridge University Press, 1998); Hobbes, Leviathan: with selected variants from the edition of 1668 , ed. with Introduction by Edwin Curley (Indianapolis, IN: Hackett, 1994).

${ }^{8}$ Thomas Hobbes, Behemoth: Or the long Parliament, reprint of the 1889 edition by Ferdinand Tönnies with a new Introduction by Stephen Holmes (Chicago, IL: The University of Chicago Press, 1990); Hobbes, "A Dialogue between a Philosopher and a Student, of the Common Laws of England," in Alan Cromartie and Quentin Skinner (eds.), Writings on Common Law and Hereditary Right (Oxford: Clarendon Press, 2005); Hobbes, The English Works of Thomas Hobbes of Malmesbury, vol. 9, ed. William Molesworth (London: Bohn, 1843).

${ }^{9}$ Hobbes develops this line of argument in Elements of Law, chs. XIV-XVII, XIX-XX; On the Citizen, chs. I-III, V; and Leviathan, chs. XIII-XVII.

${ }^{10}$ Hobbes, Leviathan, p. 80.
} 
mind, ${ }^{11}$ the majority of people must be able to agree to the social contract. Hence, it could be said that natural enmity is generally compatible with reconciliation.

This also seems to be the case with regard to hostile relations between groups. It is true that Hobbes emphasises that commonwealths are in a state of war with each other due to their independence, and that international peace treaties only provide a temporary relief. ${ }^{12}$ However, the possibility of sovereignty acquired by conquest seems to allow for lasting reconciliation with former enemies. Hobbes reasons in all of his main political works that the state is dissolved in the event of a successful enemy invasion, implying that individuals are free to submit themselves to the victor in order to retain their life and liberty. The invader may thereupon admit those who appear trustworthy enough as his subjects in order to acquire sovereignty over another nation. ${ }^{13}$ This method would allow for former enemies to establish a protectionobedience relationship, which is the basis of peace in society.

The second implication of Hobbes's argument is that enmity arises regardless of social bonds and identities. In the natural condition, everybody is potentially an enemy of everybody else, even members of the same family. Thus, Hobbes argues in Elements of Law and On the Citizen that parents have dominion over their children based on their temporary advantage in strength, which gets lost when a child becomes strong enough to kill an adult. ${ }^{14}$ In the Latin version of Leviathan, he also cites Cain's murder of Abel as an example of the state of nature. ${ }^{15}$ These passages suggest that

\footnotetext{
${ }^{11}$ Hobbes, Elements of Law, XVI.9, p. 91; On the Citizen, III.10, p. 48; Leviathan, p. 96.

${ }^{12}$ Hobbes, On the Citizen, XIII.7, pp. 144f; Leviathan, p. 78.

${ }^{13}$ Hobbes, Elements of Law, XXI.15, pp. 125f; XXII.7, pp. 128f; On the Citizen, VII.18, p. 101; VIII.12, pp. 102f; Leviathan, pp. 130f, $218 \mathrm{f}$.

${ }^{14}$ Hobbes, Elements of Law, XIV.13, pp. 80f; On the Citizen, I.13, pp. $30 \mathrm{f}$.

${ }^{15}$ Hobbes, Leviathan, p. 77, n. 7.
} 
even if there are special bonds between certain individuals, such as members of the same family, everyone could become an enemy of everybody else.

Regarding hostile relations between groups, Hobbes rejects the idea that pre-existing identities preclude reconciliation. He acknowledges that there may be negative sentiments towards foreign people, such as when he states in Leviathan that "strangers [...] commonly undervalue one another." "16 Yet Hobbes insists that oppressive government is ultimately not due to a sovereign's foreign identity, but rather caused by his ignorance of his duties. ${ }^{17}$ As Hobbes further elaborates, rulers ought to treat conquered subjects in the same way as those who were party to the social contract. ${ }^{18}$ In addition, he suggests that there may be a shift of identities:

[T] he Romans, when they had subdued many nations, to make their government digestible were wont to take away that grievance as much as they thought necessary by giving, sometimes to whole nations and sometimes to principal man of every nation they conquered, not only the privileges but also the name of Romans. ${ }^{19}$

Notwithstanding such considerations, Hobbes generally prefers an explicitly political conception of group identity, which reflects his conception of the state as a work of art. $^{20}$ As he argues, for example, in Elements of Law, a 'people' is not only a multitude of individuals that happen to live in one place, but also a 'person civil'. ${ }^{21}$

The idea that this artificial political unity trumps cultural identity is most clearly expressed in Behemoth, Hobbes's late history of the Civil War of the 1640s. Hobbes

\footnotetext{
${ }^{16}$ Hobbes, Leviathan, p. 126. Cf. "Dialogue," p. 16.

${ }^{17}$ Hobbes, Leviathan, p. 126. Cf. n. 10 on the same page for a translation of the Latin version of this passage, where Hobbes additionally mentions that oppressive government could be caused by the subjects' unwillingness to adapt to change.

${ }^{18}$ Hobbes, Leviathan, p. 131.

${ }^{19}$ Hobbes, Leviathan, p. 126f, emphasis added.

${ }^{20}$ In the brief introduction to Leviathan, Hobbes famously compares the state to an artificial animal, and to the clockwork of a watch. See Leviathan, pp. $3 \mathrm{f}$.

${ }^{21}$ Hobbes, Elements of Law, XXI.21, p. 124.
} 
admits that, despite the Act of Union, England and Scotland were not fully integrated at the time. Yet he insists that, being subject to the same sovereign, "they were mistaken, both English and Scots, in calling one another foreigners." ${ }^{22}$

Hobbes's views on enmity can be contrasted with those of Plato. In Book V of the Republic, Plato criticises Greeks who ravage each other's lands and enslave all inhabitants of a city. ${ }^{23}$ Plato apparently regards such behaviour as appropriate in wars between Greeks and barbarians, who are 'natural enemies.' Yet he believes that, among themselves, Greeks "will quarrel with the aim of being reconciled." ${ }^{24}$ By contrast, Hobbes holds that natural hostility is due to universal human characteristics, and seems to be of the view that enemies can be reconciled under the government of an absolute ruler regardless of their pre-existing social bonds and identities.

\section{The Representation and Dissolution of States}

It is well known that Hobbes's social contract theory conceives of the constitution of the state in terms of a transfer of right, whereby everyone is supposed to submit their strength and resources to a number of people. In doing so, they "appoint one man or assembly of men to bear their person, and every one to own and acknowledge himself to be author of whatsoever he that so beareth their person shall act, or cause to be acted," as Hobbes puts it in Leviathan. ${ }^{25}$ The artificial personality of the state, and to what extent it is distinct from the person of the sovereign, has been much debated.

\footnotetext{
${ }^{22}$ Hobbes, Behemoth, pp. $34 \mathrm{f}$.

${ }^{23}$ Plato, Republic, translated from the new standard Greek text, with introduction by C.D.C. Reeve (Indianapolis, IN: Hackett, 2004), 470a-471a, pp. 162-164.

${ }^{24}$ Plato, Republic, 471a3, p. 163.

${ }^{25}$ Hobbes, Leviathan, 109.
} 
Yet, in any case, Hobbes's position appears to be that people can only be united into one state as long as a sovereign effectively represents them. ${ }^{26}$

How commonwealths recognise each other is somewhat unclear and underexplored in the literature on Hobbes. William Sacksteder merely notes that enmity between nations "presuppose[s] reciprocal recognition of personhood."27 David Runciman argues - in view of the theoretical apparatus of authorisation and representation that Hobbes introduces in Leviathan - that foreign enemies will perceive the actions of individuals at war, but are unable to, thereby, discern the person of the state. ${ }^{28}$

Yet Hobbes himself does apparently not consider the recognition of another state's personality as problematic. Throughout his writings, he uses phrases suggesting that commonwealths can in practice be identified with the holder of sovereign power. For example, he writes in Elements of Law about "such commonwealths, or such monarchs, as affect war for itself." 29 In On the Citizen, he refers to "the will of the commonwealth, or of the holder of sovereign power." ${ }^{30}$ In Leviathan, Hobbes discusses the role of public ministers who act in the name of the commonwealth, including "ministers abroad [...] that represent the person of their own sovereign to foreign states." ${ }^{31}$ In addition to such considerations, Behemoth provides examples of diplomacy from the Interregnum. For instance, Hobbes describes how (after the

\footnotetext{
${ }^{26}$ For a useful overview of this debate, see Christine Chwaszcza, "The Seat of Sovereignty: Hobbes on the Artificial Person of the Commonwealth or State," Hobbes Studies 25 (2012), pp. 123-142.

${ }^{27}$ William Sacksteder, "Mutually Acceptable Glory: Rating Among Nations in Hobbes," in Peter Caws (ed.), The Causes of Quarrel: Essays on Peace, War, and Thomas Hobbes (Boston, MA: Beacon Press, 1989), pp. 97-113, here 112.

${ }^{28}$ David Runciman, Pluralism and the Personality of the State (Cambridge: Cambridge University Press, 1997), p. 17.

${ }^{29}$ Hobbes, Elements of Law, XXVIII.9, p. 177.

${ }^{30}$ Hobbes, On the Citizen, VIII.5, p. 104.

${ }^{31}$ Hobbes, Leviathan, p. 158.
} 
victory of the Parliament party in the Civil War) the Rump Parliament "received ambassadors from Portugal and from Spain, acknowledging their power., 32

Such de facto recognition presumably allows Hobbesian states to engage in diplomacy and other transactions, including international trade. ${ }^{33}$ Nonetheless, commonwealths remain in a natural state of war towards one another, and some passages in Hobbes's works suggest that they may seek to extend their authority at the cost of their neighbours. Thus, he argues in Leviathan that "for their own security [states] enlarge their dominions upon all pretences of danger and fear of invasion or assistance". ${ }^{34} \mathrm{He}$ also praises the Romans for extending privileges to conquered nations, and argues that England and Scotland should have been unified in the same way as the Roman Empire. ${ }^{35}$ In the Dialogue, Hobbes notes that great monarchies, such as England and France, developed on the basis of conquests. ${ }^{36}$

Hobbes seems to consider it self-evident that, as a work of art, the state can also be destroyed by human agency. While his main concern in Elements of Law is the commonwealth's 'death' through the 'sickness' of rebellion, he mentions in passing that "the dissolution of a commonwealth from foreign invasions" may be compared to violent death. ${ }^{37}$ In Leviathan, he also states that sovereignty is "subject to violent death by foreign war." ${ }^{38}$ However, it is important to note that, for Hobbes, the state's death does not equal the extermination of its members:

\footnotetext{
${ }^{32}$ Hobbes, Behemoth, p. 169.

${ }^{33}$ Tom Sorell argues that Hobbesian states would rely primarily on peaceful international trade to provide commodities for consumption that they cannot produce themselves. See Sorell, "Hobbes on Trade, Consumption and International Order," The Monist 89 (2006), pp. 245-258.

${ }^{34}$ Hobbes, Leviathan, p. 107.

${ }^{35}$ Hobbes, Leviathan, pp. $126 \mathrm{f}$.

${ }^{36}$ Hobbes, "Dialogue," p. 138.

${ }^{37}$ Hobbes, Elements of Law, XXVII.1, p. 162.

${ }^{38}$ Hobbes, Leviathan, p. 144.
} 
[W]hen in a war [...] the enemies get a final victory, so as (the forces of the commonwealth keeping the field no longer), there is no farther protection in their loyalty, then is the commonwealth DISSOLVED, and every man at liberty to protect himself by such courses as his own discretion shall suggest to him. ${ }^{39}$

As was previously mentioned, this liberty allows individuals to submit themselves to a foreign ruler, who thus acquires sovereignty by conquest.

Given that the victor essentially needs to establish a relationship of mutual trust with the vanquished in order to acquire sovereignty, ${ }^{40}$ invaders may not want to inflict the greatest possible harm on another nation. Rather, Hobbes's views on sovereignty by acquisition indicate that most subjects are likely to retain their life and liberty. Yet foreign invasions can, of course, still cause great suffering. In Behemoth, Hobbes mentions how Cromwell subdued Ireland "with extraordinary diligence and horrid executions $[\ldots]$; having killed or exterminated a great part of them.",41

Some statements in Hobbes's writings further suggest that enemies specifically target the holder of sovereign power. ${ }^{42}$ In view of the dangers to the person of the sovereign, Hobbes argues in Elements of Law that "[t]he head always is that part, not only where the care resideth, but also against which the stroke of an enemy most commonly is directed. ${ }^{, 43}$ In Behemoth, Hobbes points out that the fact that a former sovereign is still alive poses a potential threat to those who have deprived him of his power. ${ }^{44}$ That

\footnotetext{
${ }^{39}$ Hobbes, Leviathan, pp. 218f, capitalisation in the original.

${ }^{40}$ On the role of trust in Hobbes's account of sovereignty by acquisition, see Deborah Baumgold, “'Trust' in Hobbes's Political Thought," Political Theory 20 (2013), pp. 1-20.

${ }^{41}$ Hobbes, Behemoth, p. 163. Through the interlocutor's voice, Hobbes blames the misery caused by this war on the influence of religious doctrines.

${ }^{42}$ This may also be the case in conflicts between democracies or aristocracies. Hobbes holds that, in such states, a 'dictator' exercises sovereignty in times of war. See Hobbes, Elements of Law, XX.17, p. 116; On the Citizen, XX.17, p. 126; and Leviathan, p. 122.

${ }^{43}$ Hobbes, Elements of Law, XXIV.2, p. 136. In this passage, Hobbes still invokes the conventional notion of the ruler as the head of state. From On the Citizen, VI.19, pp. 88f, onwards, he instead compares the sovereign to the human soul, which sets the body in motion.

${ }^{44}$ Hobbes, Behemoth, p. 133.
} 
the sovereign requires particular protection in times of war is further suggested by a passage in Leviathan, according to which every subject ought "to protect in war the authority by which he is himself protected in time of peace." 45

The picture emerging from these passages is that, on the one hand, rulers recognise each other's sovereignty and maintain diplomatic relations. On the other hand, sovereigns may be specifically targeted at war, ultimately serving as disposable figureheads. Far from implicating the annihilation of the civilian population, the 'violent death' of the state, therefore, prepares the ground for reconciliation, i.e., it allows former subjects to submit themselves to a new sovereign.

\section{Artificial Equality as a Source of Security}

So far it has been shown that natural enmity, for Hobbes, does not preclude reconciliation. The latter is facilitated by the fact that states can be decomposed and reassembled in the aftermath of foreign invasions. As will be further demonstrated in this section, Hobbesian commonwealths may also coexist peacefully for considerable amounts of time due to what may be called their artificial equality.

A characteristic feature of the interpersonal state of nature is that "the weakest has strength enough to kill the strongest." ${ }^{, 46}$ In other words, human beings are roughly equal in their capacity to kill and get killed, which is one of the reasons why a war of all against all would, according to Hobbes, materialise in this condition. Interpreters have noted that this assumption does not hold true in international relations, since

\footnotetext{
${ }^{45}$ Hobbes, Leviathan, p. 490.

${ }^{46}$ Hobbes, Leviathan, p. 74.
} 
there are differences in power between states. ${ }^{47}$ It has also been suggested that

Hobbesian commonwealths would have an incentive to create an imbalance of power by forming defensive leagues. ${ }^{48}$ However, there are reasons to believe that some kind of equality between states might actually have beneficial effects, a possibility that has, to my knowledge, not been considered in the literature on Hobbes.

To begin with, it seems clear that international relations and the state of nature are not meant to be identical in all respects. One difference, which Hobbes acknowledges in

On the Citizen, is that there can be times of international peace:

[T] hose who have not grown together into unity of person are, as shown above at v.6, in a state of enmity with each other. Never mind that they are not always fighting (for enemies too make truces); hostility is adequately shown by distrust, and by the fact that the borders of their commonwealths, Kingdoms and empires, armed and garrisoned, with the posture and appearance of gladiators, look across at each other like enemies, even when they are not striking each other. ${ }^{49}$

While Hobbes interprets armed borders and the appearance of gladiators as evidence of a natural state of war between commonwealths, he leaves open the possibility of periods without actual warfare. Given that the state of war is defined in terms of a "will to contend by force," ${ }^{, 50}$ states must surely be prepared to attack one another. Yet it seems that they may also be deterred from putting their intention into practice by the very defensive devices that Hobbes takes as evidence of their hostility. Elsewhere in On the Citizen, Hobbes emphasises that international peace agreements will be

\footnotetext{
${ }^{47}$ See, for instance, Mark A. Heller, "The Use \& Abuse of Hobbes: The State of Nature in International Relations," Polity 13 (1980), pp. 21-32. During the Cold War, commentators have also addressed the question of whether nuclear proliferation could eventually lead to equality of vulnerability. See esp. David Gauthier, The Logic of Leviathan: The Moral and Political Theory of Thomas Hobbes (Oxford: Clarendon Press, 1969), pp. 207f; and Howard Warrender, The Political Philosophy of Hobbes: His Theory of Obligation (Oxford: Clarendon Press, 1957), p. 119.

${ }^{48}$ David Boucher, "Inter-Community \& International Relations in the Political Philosophy of Hobbes", Polity 23 (1990), pp. 207-232, here 226f.

${ }^{49}$ Hobbes, On the Citizen, XVII.27, pp. 231f, capitalisation in the original.

${ }^{50}$ Hobbes, On the Citizen, I.12, pp. $29 \mathrm{f}$.
} 
fragile and uncertain because states are not restrained by a common power. ${ }^{51}$ This confirms that there can, indeed, be times of peace. Nevertheless, Hobbes believes that states must ultimately rely on their own power to defend themselves.

Hobbes's discussion of the international state of nature in Leviathan also indicates that the hostility between commonwealths does not have the same catastrophic effects on most people as the war of all against all:

[K]ings and persons of sovereign authority, because of their independency, are in continual jealousies and in the state and posture of gladiators, having their weapons pointing and their eyes fixed on one another, that is, their forts, garrisons, and guns upon the frontiers of their kingdoms, and continual spies upon their neighbours, which is a posture of war. But because they uphold thereby the industry of their subjects, there does not follow from it that misery which accompanies the liberty of particular men. $^{52}$

As previously in On the Citizen, Hobbes argues here that international relations is a state of war in which actors distrust one another, and must be prepared to use their own capacities for defence. However, he also emphasises that the international state of nature is compatible with peace within the commonwealth.

While Hobbes does not develop the analogy of the state of nature and international relations beyond the quoted passages, his more detailed comments on defence suggest that the international realm provides greater room for peaceful coexistence. When discussing the requirements of state formation in Elements of Law, Hobbes argues that the number of individuals that agree to the social contract "must be so great, that the odds of a few which the enemy may have, be no certain and sensible advantage." ${ }^{, 53}$ In On the Citizen, Hobbes likewise describes insufficient numbers as an incentive to

\footnotetext{
${ }^{51}$ Hobbes, On the Citizen, X.17, p. 126.

${ }^{52}$ Hobbes, Leviathan, p. 78.

${ }^{53}$ Hobbes, Elements of Law, XIX.3, p. 104.
} 
aggression by foreign enemies, which would undermine the security of a newly formed state. ${ }^{54}$ In Leviathan, he puts this point as follows:

The multitude sufficient to confide in or our security is not determined by any certain number, but by comparison with the enemy we fear, and is then sufficient, when the odds of the enemy is not of so visible and conspicuous moment, to determine the event of war, as to move him to attempt. ${ }^{55}$

As an additional requirement of state formation, Hobbes emphasises throughout his writings that the people's force and resources must be truly united by an absolute sovereign. In Leviathan, he thus points out that a large but divided commonwealth is "easily $[\ldots]$ subdued by a very few that agree together.",56

These considerations are echoed in Hobbes's latest version of the analogy between the state of nature and international relations in the Dialogue, according to which

mutual fear may keep [commonwealths] quiet for a time, but upon every visible advantage they will invade one another, and the most visible advantage is then, when the one Nation is obedient to their King, and the other not; $[\ldots] .{ }^{57}$

Hobbes does not deny that commonwealths can coexist despite being in a state of nature with one another, yet he seems to argue that peace between them only lasts as long as each of them is well ordered and powerful enough to deter wars of aggression. Sufficient public funds to maintain military capability, thereby, might to be a good indicator of a state's strength and unity. This is suggested by Hobbes's remark that "want of publick Treasure inviteth Neigbhour Kings to incorach."

\footnotetext{
${ }^{54}$ Hobbes, On the Citizen, V.3, p. 70.

${ }^{55}$ Hobbes, Leviathan, p. 107, emphasis added. Cf. Leviathan, p. 132.

${ }^{56}$ Hobbes, Leviathan, p. 107.

${ }^{57}$ Hobbes, "Dialogue," p. 12, capitalisation in the original.

${ }^{58}$ Hobbes, "Dialogue," pp. 16f, capitalisation in the original.
} 
Regardless of how commonwealths come to know each other's strength and unity, Hobbes's statements indicate that the lack of an obvious difference in power between them enhances their security and facilitates coexistence. This suggests that the artificial equality of Hobbesian states (which is due to the fact that different states have a similar number of obedient subjects) has a contrary effect to the natural equality of human beings. Rather than causing distrust and pre-emptive attacks, the rough equality of commonwealths is a disincentive to war.

\section{Prudence and Self-restraint in Warfare}

It follows from what has been said that, unlike individuals in the natural condition, sovereigns are not compelled to wage war out of fear for their own survival. Rather, they seem to be able to maintain largely peaceful relations with their neighbours based on deterrence and mutual recognition of each other's power. Provided the condition of artificial equality is met, the potential losses for the sovereign would, as will be shown below, often outweigh the likely benefits of war.

Hobbes seems to presume that people normally only revert to violence when it appears beneficial. In Elements of Law and Leviathan, he considers the possibility that exceptionally strong passions inhibit the capacity to reason, which he calls madness. ${ }^{59}$ Such a disposition could motivate irrational acts of hostility, as is suggested by the remark in Elements of Law that a rebellion without hope of success would be madness. ${ }^{60}$ However, Hobbes maintains in Leviathan that only those who have the capacity to reason can hold the sovereign's office, ${ }^{61}$ which seems to exclude madmen as potential rulers. What is more, Hobbes's recurring comments on the need for

\footnotetext{
${ }^{59}$ Hobbes, Elements of Law, X.9, p. 63; Leviathan, p. 41.

${ }^{60}$ Hobbes, Elements of Law, XXVII.1, p. 163.

${ }^{61}$ Hobbes, Leviathan, p. 121.
} 
counsel and intelligence suggest that the sovereign's reasoning can also be artificially improved. In the Dialogue, he states, for instance, that rulers ought to gain "Knowledge in some measure of the strength, Advantages and Designs of the Enemy, and the Manner and Degree of the Danger that may from thence arise." ${ }^{62}$

Hobbes sometimes refers to states waging war for gain, such as when he points out in On the Citizen that Rome and Athens acquired so many goods in war that they could distribute money to poorer citizens. ${ }^{63}$ While this makes warfare appear beneficial, Hobbes cautions that "as a means of gain, military activity is like gambling; in most cases it reduces a person's property; very few succeed." ${ }^{, 64}$ Even if wars for gain do not carry a direct security risk, great losses might ultimately endanger the sovereign's self-preservation. As was mentioned above, a lack of public funds encourages foreign enemies to invade. Hence, it seems that rulers might lose more than they could possibly gain through war. Moreover, Hobbes argues in Leviathan that trade is a less risky, and therefore preferable, way to acquire goods from abroad. ${ }^{65}$

Despite his expressed preference for trade, Hobbes suggests that wars are sometimes necessary to acquire immovable resources. In Leviathan, he defines colonies as settlements in foreign lands, which were either "formerly void of inhabitants, or made void then by war." ${ }^{, 66}$ Yet even if colonisation might require the use of military force, there would still be reasons to exercise some restraint:

The multitude of poor (and yet strong) people still increasing, they are to be transplanted into countries not sufficiently inhabited, where, nevertheless, they are not

\footnotetext{
${ }^{62}$ Hobbes, "Dialogue," pp. 20f, capitalisation in the original.

${ }^{63}$ Hobbes, On the Citizen, XIII.14, p. 150.

${ }^{64}$ Hobbes, On the Citizen, XIII.14, p. 150.

${ }^{65}$ Hobbes, Leviathan, p. 160.

${ }^{66}$ Hobbes, Leviathan, p. 164.
} 
to exterminate those they find there, but constrain them to inhabit closer together, and not range a great deal of ground to snatch what they find, but to court each little plot with art and labour, to give them sustenance in due season. ${ }^{67}$

While Hobbes thus regards it as permissible to acquire new lands by force, he also argues that native inhabitants should not be exterminated. This point is not further elaborated in his works. However, there may be both moral and prudential reasons for exercising restraint in wars that are waged to establish settlements.

Given the need for resources to sustain an army in the field, making gain may also be a subordinate motive in wars that are fought for other reasons. While Hobbes's works contain no reflection on the devastating effects of pillaging armies, one passage in Leviathan seems to indicate that he prefers military campaigns to be paid for by public funds. Thus, he reasons that gold and silver allow commonwealths to "stretch out their arms, when need is, into foreign countries, and supply not only private subjects that travel, but also whole armies with provision.. ${ }^{, 68}$ In Behemoth, Hobbes further considers the possibility that pillaging the enemy's population may be detrimental to the main motive of war. This is exemplified by the Scottish invasion of Northern England prior to the outbreak of civil war, intended to deliver a petition to the king who was then marching towards Scotland. The Scots were "giving out all the way, that their march should be without damage to the country." 69

Glory is another motive of war that features prominently in Hobbes's writings. As he notes in both Elements of Law and Leviathan, victories in battle are generally

\footnotetext{
${ }^{67}$ Hobbes, Leviathan, pp. 228f, emphasis added.

${ }^{68}$ Hobbes, Leviathan, p. 164.

${ }^{69}$ Hobbes, Behemoth, p. 35
} 
considered honourable. ${ }^{70} \mathrm{He}$ also states that rulers who subdued other states "are remembered for it in after ages with honour."71 Yet despite the prospect of military honours, Hobbes expresses his reservations regarding wars that are solely motivated by the desire of glory. For instance, he claims in Elements of Law that

such commonwealths, or such monarchs, as affect war for itself, that is to say, out of ambition, or of vain-glory, or that make account to revenge every little injury, or disgrace done by their neighbours, if they ruin not themselves, their fortune must be better than they have reason to expect. ${ }^{72}$

Like wars for gain, wars for glory thus require states and sovereigns to take a gamble, and Hobbes suggests that it is likely that the risk does not pay off. Indeed, the potential losses clearly seem to outweigh the possible gains in such cases, given that Hobbes mentions the great likelihood of rulers ruining themselves.

Even if wars for glory end in victory, they may ultimately have detrimental effects.

Hobbes considers this possibility in Leviathan, where he mentions

the insatiable appetite, or Bulimia, of enlarging dominion, with the incurable wounds thereby many times received from the enemy, and the wens, of ununited conquests, which are many times a burden, and with less danger lost than kept. ${ }^{73}$

Hence, Hobbes thinks that unlimited expansion all but improves a state's security, because foreign acquisitions come at a cost and can be difficult to maintain. This does not necessarily imply that he is fiercely opposed to imperial expansion. However, Hobbes is certainly against wars for glory that are conducted without consideration of their security implications. What is more, as has been shown above, he argues for the

\footnotetext{
${ }^{70}$ Hobbes, Elements of Law, VIII.5, p. 49; Leviathan, p. 53.

${ }^{71}$ Hobbes, Leviathan, p. 107.

${ }^{72}$ Hobbes, Elements of Law, XXVIII.9, p. 177.

${ }^{73}$ Hobbes, Leviathan, p. 218.
} 
need to re-establish a protection-obedience relationship after a successful foreign invasion, as this is the only basis for lasting peace.

Hobbes further elaborates this view in the Dialogue, thereby referring to Alexander the Great's unsustainable conquests as a paradigmatic example:

The Subjects of those Kings who affect the Glory, and imitate the Actions of Alexander the Great, have not always the most comfortable lives, nor do such Kings usually very long enjoy their Conquests. They March to and fro perpetually, as upon a Plank sustained only in the midst, and when one end rises, down goes the other. ${ }^{74}$

In other words, unlimited expansionism is likely to undermine the conditions under which the glory of conquest can be enjoyed. Further examples of such prudential advice to glory-seeking sovereigns can be found in Hobbes's early translation of Thucydides' History of the Peloponnesian War. In this work we read, for instance, that "it were madness to invade such, whom conquering you cannot keep; and failing, should lose the means for ever after to attempt the same again." 75

As in the case of wars of gain, there are also alternative sources of glory that could substitute warfare. In Elements to Law, Hobbes notes that monarchs may instead distinguish themselves in other fields, such music or poetry. ${ }^{76}$ In Leviathan, he likewise suggests that only some kings seek glory in new conquests, while others aim for sensual pleasures or excellence in some art. ${ }^{77}$ Given these less risky alternatives, it seems that sovereigns would be well advised to avoid wars for glory.

\section{Conclusion}

\footnotetext{
${ }^{74}$ Hobbes, "Dialogue," p. 16, capitalisation in the original.

${ }^{75}$ Hobbes, The English Works, vol. 9, p. 124.

${ }^{76}$ Hobbes, Elements of Law, VII.7, p. 45.

${ }^{77}$ Hobbes, Leviathan, p. 58.
} 
This article has shown the dynamic relationship between the notions of nature and artifice in Hobbes's international political thought. Given that commonwealths are in a state of nature, they face a constant threat of wars of aggression, and ultimately have to rely on their own resources to defend themselves. Sovereigns, in particular, have to fear for their lives and liberty, as they are likely to be specifically targeted at war. Furthermore, Hobbes suggests that rulers can only enjoy relative security as long as their states are well ordered and powerful enough to deter foreign invasions.

Despite this, sovereigns are in a better position than individuals in the state of nature. They are not forced to fight for their own survival, but could maintain peaceful relations with their neighbours for most of the time. Hobbes's statements suggest that the coexistence of commonwealths is enabled by their rough equality in power. As long as different states are made up of similar numbers of individuals who are equally obedient to their respective sovereigns, there would be prudential reasons not to attack one another. Hence, it has been argued that the artificial equality of states has a contrary effect to the natural equality of individuals in the state of nature.

Even when states do engage in warfare, this does not necessarily have the same disastrous effects as the war of all against all in the natural condition. Hobbes argues that, in order to sustain their foreign conquests, invaders eventually need to reestablish a protection-obedience relationship. The reconciliation of former enemies is, thereby, facilitated by the artificiality of states, which allows for them to be decomposed and reassembled. Thus, Hobbes also denies that cultural differences, which might be regarded as 'natural,' constitute an insuperable obstacle to peace. 
Ultimately, the artificial political unity that results from submission to an absolute sovereign is more important than any pre-existing identities.

These findings further elucidate the widely acknowledged differences between the international and interpersonal states of nature. Moreover, they help to explain why Hobbes does not provide something akin to a theory of international relations. ${ }^{78}$ It seems that, in his view, foreign affairs can be reduced to a matter of either prudence or political philosophy. Usually the conduct of international relations will be subject to the judgment of sovereigns, who ought to govern well, and avoid unnecessary wars, for their own good. ${ }^{79}$ In the extreme case of a successful foreign invasion, people are permitted to submit themselves to the victor, who ought to accept them as his subjects in order to acquire sovereignty by acquisition. In this event, international relations would simply be a matter of applying political philosophy.

\footnotetext{
${ }^{78}$ Hobbes does, for instance, not provide theoretical reflection on the question of what constraints the structure of the international system imposes upon individual states. Cf. R.B.J. Walker, "Hobbes, Origins, Limits," in Raia Prokhovnik and Gabriella Slomp (eds.), International Political Theory After Hobbes: Analysis, Interpretation and Orientation (Basingstoke, UK: Palgrave Macmillan, 2010), pp. 168-188, here 180.

${ }^{79}$ One question that has not been addressed here is that of the relationship between the laws of nature, which dictate that human beings seek peace, and prudence.
} 